\title{
Loranthus europaeus as an Alternative Medicine in Treatment of Acute Cutaneous Lesihmaniasis: Review Article
}

\author{
Khalifa E. Sharquie ${ }^{1,2 *}$, Adil A. Noaimi1,2, Banaz A. Saleh ${ }^{3}$ \\ ${ }^{1}$ Department of Dermatology, College of Medicine, University of Baghdad, Baghdad, Iraqi \\ ${ }^{2}$ Arab Board for Dermatology \& Venereology, College of Medicine, Baghdad Teaching Hospital, Medical City, \\ Baghdad, Iraq \\ ${ }^{3}$ Department of Dermatology, Baghdad Teaching Hospital, Medical City, Baghdad, Iraq \\ Email: "ksharquie@ymail.com, adilnoaimi@yahoo.com,banazali2014@yahoo.com
}

Received 29 November 2015; accepted 7 March 2016; published 10 March 2016

Copyright (C) 2016 by authors and Scientific Research Publishing Inc.

This work is licensed under the Creative Commons Attribution International License (CC BY).

http://creativecommons.org/licenses/by/4.0/

(c) (i) Open Access

\begin{abstract}
Loranthus europaeus (LE) is a well-known medical plant that has been used as a folk medicine for long time ago. Recently many different researches have shown that it contains many bioactive compounds like: flavonoids, alkaloids, terpenoides, phenolic acids and others. Cutaneous Leishmaniasisis (CL) is an endemic disease in Iraq since ancient time and now it is running major outbreaks. There are many modalities of treatments but researchers are always seeking for new treatments. Most recently Loranthus europaeus has been tried in treatment of CL in a form of $40 \%$ ointment and gives a very encouraging result when compared with other standard treatments.
\end{abstract}

\section{Keywords}

Cutaneous Leishmaniasisis, Loranthus europaeus, Alternative Medicine

\section{Introduction}

Cutaneous Leishmaniasisis (CL), is a parasitic disease caused by 20 Leishmania species, and it is considered a major public health issue as it currently affects 12 million people [1]. Iraq is considered as endemic country and the most common causative species are L. major (60\%) and L. tropica (40\%) that approved recently by PCR technique which considered as the most sensitive and specific technique [2] [3]. Iraq is suffering from an ongoing outbreak of the disease, due to floods that occurred because of heavy rains and by terrorist people that close

*Corresponding author.

How to cite this paper: Sharquie, K.E., Noaimi, A.A. and Saleh, B.A. (2016) Loranthus europaeus as an Alternative Medicine in Treatment of Acute Cutaneous Lesihmaniasis: Review Article. Journal of Cosmetics, Dermatological Sciences and Applications, 6, 24-33. http://dx.doi.org/10.4236/icdsa.2016.61004 
the gates on the rivers that result in rise of water level and sank of many towns and villages and this leads to displaced and spread of rodents; the reservoir of leishmaniasias, and also due to continuous wars, heavy displacement of thousands of peoples from their place and living in bad conditions and poor housing led to more exposures to sand fly. Although it is a self-limiting disease however spontaneous cure may took several months or even years, and if left untreated, CL leaves permanent ugly scars and may cause disfigurement [4]. Many different treatment modalities are used for treatment; they are either systemically used including pentavalent antimonial compounds (sodium stebogluconate and meglumie antimoniate); which have been used sixth decade ago, but due to its intramuscular use, long treatment periods, a serious side effects, not always available and the emergence of antimonial-resistant [5]-[7], for these reasons antimonial drugs have been replaced by other drugs such as antifungal (azole \& amphotericin B [8]-[11]), dapsone [12], and oral zinc sulfate [4]. While local treatment had been effectively used either itralesionally used like pentavalent antimony compounds [13], hypertonic saline [14], 2\% zinc sulfate solution [15] and metronidazole [16], or topically applied such as paromomycin [17] and recently the encouraging result obtained with 25\% podophyllin solution [18] and microwave therapy [19].

The reason for seeking an alternative medicine is increasing because the modern drugs are simply not available, expensive or due to resistance to the treatment and emergence of new species of parasite. Perhaps $80 \%$ of the world's populations rely solely upon medicinal plants as the source of remedies for treatment of the disease. Herbal remedies have been used for long period of time in both traditional and modern medicine around world, where different plants of medical value are traditionally used worldwide for treatment of leishmaniasis [20][22].

Many in vitro studies done about natural product from plants for treatment of leishmaniasis with the excellent activity against leishmania parasite, and the most common bioactive natural compounds are: Alkaloids, quinones, terpenes (monoterpens and triterpenes), saponins, flavonoids especially quercetin [23] [24] and phenolic compound including caffiec acid [25] that showed antileishmanial activity.

In this review we selected the medicinal plant Loranthus europaeus based on the fact that this plant was not previously used as antileishmanial agent, and because it contains many of the bioactive compound that had been extracted from many plants and investigated in many in vitro studies and showed a well antileishmanial activity.

\subsection{Loranthus europaeus (LE)}

Synonoms: (Latin name [26]: Loranthus europaeus Jacquin, in Europe [27]: European yellow mistelotoe, Summer mistletoe, in Italy [28]: Vischio quercino, in Arabic [29]: Hib el-debgh, Habet pukour, Fulful Hawa and Balaw-Demoke in kirdish [30]).

\subsection{Classification [31]}

Loranthus is a genus of parasitic plants that grow on the branches of woody trees. It belongs to the family Loranthaceae (the showy mistletoe family) and this genus has 1253 species (Figure 1) [32] [33].

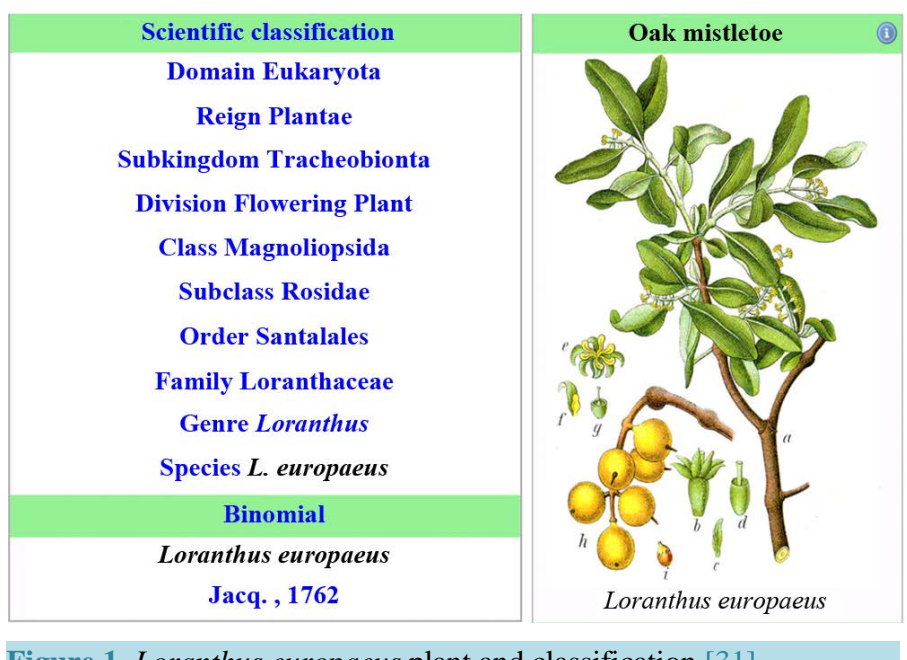

Figure 1. Loranthus europaeus plant and classification [31]. 
$\boldsymbol{L E}$ is a hemi-parasite mistletoe, it is a deciduous plant (flower are produced in May and June) with dull brown twinges, the fruit is yellow roundish berry, which remain sticky even after dried, the fruits ripen in late autumn and gradually fall off in late winter, the plant grows vigorously on aging trees mostly on branches of oak, and chestnut as host trees and once established, the mistletoe take minerals and water from the host tree, and block sunlight through its dense foliage, the most important vectors of yellow mistletoe are birds [34].

$L E$ is widely distributed in south-west Europe, south Russia, Anatolia, Iran and Iraq [35]. In Iraq, LE distributed in the north of country especially in Ammadia, Roundoze and Sulymania (Figures 2-4) [29] [30].

\subsection{Loranthus europaeus in the Folk Medicine}

$L E$ had a known importance in Iraqi folk medicine for long time ago, for treating boils and abscesses, where a dry fruit used in form of poultice after mastication and moisture in the mouth, it is claimed that the poultice cause maturation and acceleration in the drain of pus from the boils, however the mechanism of action was unknown, until 2006, a study from Iraq done to evaluate the anti-inflammatory effect of the plant in animals, which explained the effect of $L E$ oil extract in pyogenic inflammation and concluded that the oil extract may act as immunomodulator during bacterial infection and may contain substance act as a chemotactic agent for neutrophile and promote macrophage activity [29].

\subsection{Active Constituents of Loranthus Genus}

Loranthus species are known to produce a variety of bioactive compounds and some of them used in a variety of disease such as:

1) Sesquiterpene lactones from $L$. parasiticus used for the treatment of schizophrenia [38].

2) (+)-catechin, 3,4-dimethoxycinnamylalcohol and 3,4,5-trimethoxycinnamyl alcohol extracted from L. globosus for antimicrobial and antifungal properties [39].

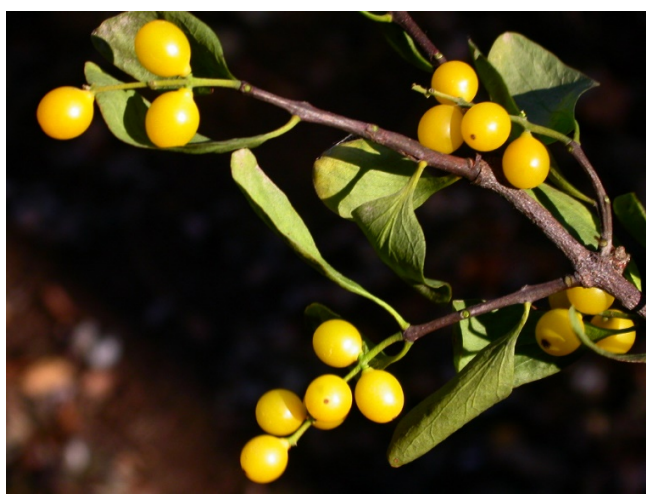

Figure 2. Loranthus europaeus plant [36].

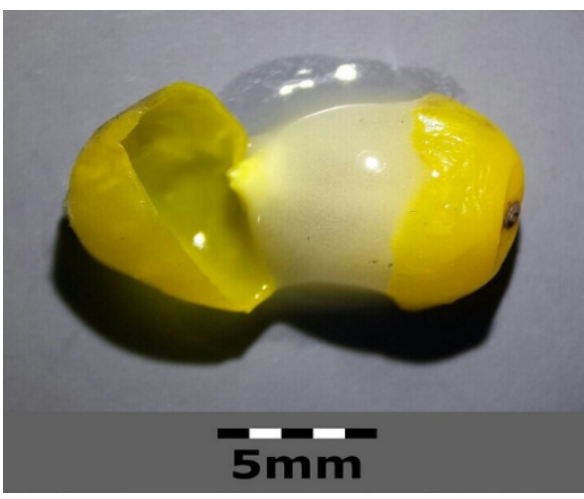

(a)

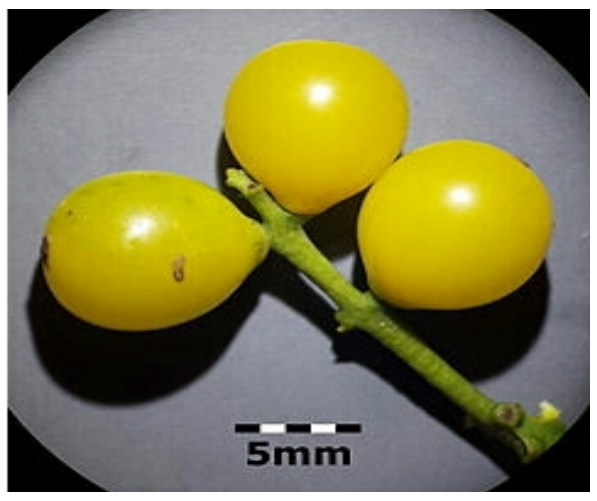

(b)

Figure 3. Freshfruit of Loranthus europaeus [37]. 


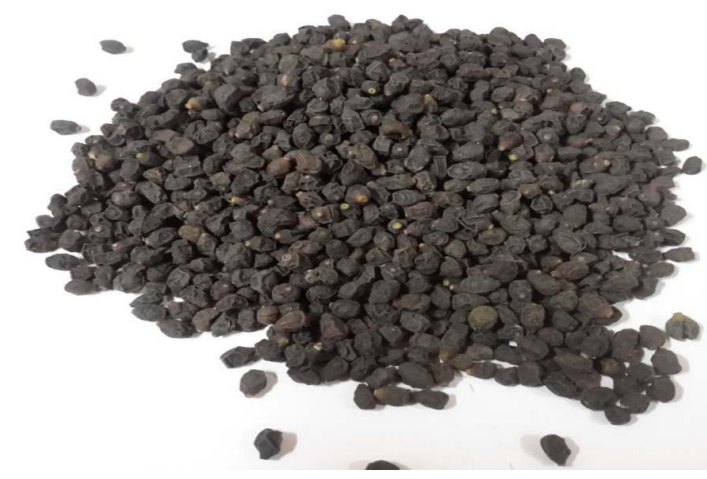

Figure 4. Dry fruit of Loranthus europaeus.

3) Triterpenoids from $L$. grewinkii and L. falcatus [40] [41].

4) Kaempferol 3-O- $\alpha$-D-rhamnoside, kaempferol 3,7-di-O- $\beta$-D-glucoside, quercetin 3-O- $\alpha$-D-rhamnoside and quercetin 3-O- $\beta$-D-glucoside from $L$. kaoi and $L$. europaeus [42] [43].

5) A cytotoxin from L. parasiticus [44], and phenolics from L. longiflorus [45].

6) Flavonol rhmnoside from L. tanakae and cytoxic effects on the human tumour cell line [46].

Many of these compound have a biological activities such as antihypertensive and anti-diabetic effect of $L$. bengwensis [47] [48], and antiviral activity of L. parasiticus [49].

Loranthus europaeus is one species of Lorantheceae, and many studies showed that $L E$ contain many biological compounds including: Flavonoids (kaempherol, quercetin [43] and rutin [50]), alkaloids [51], glycosides, carbohydrate, aldehyde, ketones, protein, polysaccharide [52], terpenes (monoterpens and triterpenes [52] [53]), phenolic acid (caffeic and gallic acid) [54], lipid include Palmitic acid, paraffin $\mathrm{C}_{30} \mathrm{H}_{62}$ and wax alcohol and sugar (sucrose) [55].

Many of these active ingredients had been extracted from different plants and investigated in many in vitro studies for antileishmanial activity, such as: Alkaloids that are able to intercalate DNA or interfere with the metabolism of aromatic amino acids in the parasite [56].

As the iron $\left(\mathrm{Fe}^{2+}\right)$ are essential for organism growth and replication inside macrophage, a chelator effect of the quercetin had been evaluated in interference of parasite's iron metabolism and showed leishmanicidal action [57]-[59]. Quercetin also can induce the production of reactive oxygen species (ROS), that leading to mitochondrial dysfunction and ultimately causing parasite death [60] [61].

The leishmanicidal activity of caffeic acid may attribute to the interaction of with iron and it could cause change in the structure of cytoplasmic proteins that inhibit cell division [25].

In addition to the above antileishmanial effect, the $L E$ contain polysaccharide and Aldehyde that showed action in an accelerate wound healing [52], this might contribute to rapid ulcer healing of CL and decrease scar formation which is the main target in CL treatment, and also the antimicrobial effect that prevent secondary bacterial infection [30].

\section{Pharmacological Effects of Loranthus europaeus According to in Vitro Studies}

\subsection{Antioxidant Effect}

In one study revealed that the presence of monoterpene in oily extract of $L E$ seeds account for antioxidative action [53]. While other study showed that the pure antioxidant including gallic acid, caffeic acid and quercetin account for this action [54].

\subsection{Wound and Burn Healing Effect}

The efficacy of topical oily extract of $L E$ seeds was investigated in wound healing on excision wound in 18 rabbits [52]. After a preparation of ointment from plant seeds and many preliminary biochemical analysis were carried out to find the chemical contents of oily extract which found the presence of glycosides, carbohydrate, aldehyde, ketones, tritrpenoides, protein and polysaccharide, then the wound evaluated daily macroscopically to measure contraction rate, hyperemia, exudate and scab formation, while microscopically for neutrophil, macro- 
phage infiltration, re-epithelzation, fibroblast proliferation with collagen production and new blood capillary formation [52].

The study showed that macrophage activated by polysaccharide which stimulates the fibroblast proliferation with subsequent of myoproliferation at periphery of the wound which has important role in wound contraction [62] [63]. The daily contraction rate of wound treated by topical ointment of $L E$ was $1.8 \mathrm{~mm} /$ day. The presence of polysaccharides also has a role in activate macrophage to secrete cytokines such platelet derived activating factor (PDAF), transforming growth beta factor (TG $\beta$ F), interleukin (IL), fibroblast growth factor (FGF), insulin growth factor (IGF-1), epidermal growth factor (EGF), these cytokines are essential for fibroblast proliferation, angiogenesis, and chemotactic of neutrophil [64] and may explained the high infiltration of neutrophil in wound treated by $L E$ oil extract particularly in early inflammatory phase. Since oxygen is required for the synthesis of collagen by fibroblast, the extract might improve angiogenesis or vascular supply and make more oxygen available to improve collagen formation for wound healing [65]. During wound healing process, epithelial cells proliferate and migrate from the edge of the wound and eventually cover the wound with new skin [66], by lysing collagen enzyme, the epithelial cells move across the wound and attach to viable tissue, the proliferation and migration of the epithelial cells is dependent on adequate supply of oxygen $\left(\mathrm{O}_{2}\right)$ [67], therefore, the increased presence of $\mathrm{O}_{2}$ caused by $L E$ oil extract. There was also a relationship between healing process and scab formation [68], the appearance of scab layer in treated wound by $L E$ oil extract can behave like semi-occlusive dressing that protect the wound and promote of migration of epithelium and provide more cosmetic results. Aldehyde in addition to polysaccharide also reported to induce healing properties by increase cellular proliferation and collagen synthesis at wound edge [69].

In other study, when a hot watery and alcoholic extract of seeds of $L E$ with different concentration used topically in treatment of burns in mice showed complete cure of burns [70].

\subsection{Antimicrobial Effect}

The effects of topical $L E$ seeds oil extract had been investigated on pyogenic inflammation in excision wound created in the 24 rabbits were the wound of the animals contaminated by staphylococcus aurous bacteria, then the wound evaluated macroscopically which showed increase in hyperemia and exudation in the first days and then gradually disappearance, while microscopically show significant neutrophil and macrophage infiltration. During bacterial infection there was a massive production of pro-inflammatory cytokines including IL1 and IL 6 [71], which mediate for chemotactic of neutrophils [64], that responsible for eradicating of invasive bacteria and necrotic tissue from wound site [72], many authors emphasized that polysaccharide promote macrophage activity through binding to glycoprotein surface receptor [73] and these activated macrophage play a role in phagocytosis of killed bacteria and damaged tissue and stimulate the chemotaxis, proliferation of fibroblast, collagen synthesis and induce angiogenesis. On basis of this study one can concluded that the oil extract of $L E$ seeds may acts as immuomoduialtors during bacterial infection and contain substance that act as chemotactic agent for neutrophil and promote macrophage activity [29].

\subsection{Anti-Inflammatory Effect}

The inflammatory effect of ethyl acetate and methanol extract of $L E$ were evaluated in the acute inflammation in rats when the extract given intraperitoneal, preliminary phytochemical investigated revealed the presence of Flavonoids (quercetin, kaempherol and rutin) and trace of alkaloids plays a crucial role in the ability of suppression of acute inflammation [50].

\subsection{Antitumor Effect}

Mistletoe extract have been widely used in complementary cancer therapy in Europe [74], in a retrospective study with 700 lymphoma patients whose received mistletoe extract suggest this therapy to be beneficial [75]. In one study the effect of high concentration $L E$ ethyl acetate and chloroform extract show to have cytotoxic effects on the growth of rhabdomyosarcoma (RD) and rat embryo fibroblast (REF) cell lines [51]. The phytochemical evaluation of extract show that the flavonoid are the major constituents and produced many biological activities when administrated both in pure form or within extract these include immune regulation, antioxidant, antibacterial and play important role in modulating cell proliferation in addition to alkaloids, the antitumor effect showed formation of variable adducts with DNA, proteins and other macromolecules and consequently affecting 
cells divisions by affecting the time of S and/or G2 phases, while in the same study the low consecration of extract produced proliferative activity in RD and REF cells, so careful should take when using such extract in traditional medicine especially for treatment of tumors [76].

\subsection{Immunomodulator Effect}

When the flavonoids and terpenoides isolated from $L E$ and tested on mouse spleen lymphocyte proliferation, both compounds show activation of unstimulated lymphocytes in dose dependent manner, so considered as potential immunomodulators [77].

\subsection{Neuroprotective Effect}

In vitro study $L E$ fruits show antioxidant and neuroprotective effect in whom Ibn Sian described it in Cannon of Medicine in management of stroke [78].

\subsection{Side Effects of Loranthus europaeus}

Topical poultice of dry fruit of $L E$ after mastication in mouth used in treatment of boils and abscess which cause maturation and drain of pus from it and this way used for long time ago in folk medicine in Iraq and no any topical and systemic sides effects had been mentioned in medical literatures from use it topically.

In recent years many in vitro studies showed sides effects from used it systemically including:

$L E$ chloroform extract was prepared and used orally for investigation of genotoxic effects in different doses, on bone marrow and peripheral blood cells of mice. Result showed large dose of extract decrease mitotic index and increase chromosomal aberration and significantly decrease the total and different white blood cell counts when compared with lower dose [79].

In other study, gene toxicity of chloroform and ethyl acetate extract of $L E$ fruits evaluated with different doses on bone marrow and spleen cells of mice in comparable with methotrexate, the extracts contain different amount of alkaloids and flavonoid, showed increasing the amount of alkaloids leads to increase clastogenicity effect while increasing in the amount of flavonoids offer anti-clastogenic effect, and the genotoxic effect after seven successive days was less toxic than methotrexate [80].

Most recently [81] we used $L E$ as topical $40 \%$ ointment in the treatment of acute CL as alternative medicine through case therapeutic, comparative study and compared with topical $25 \%$ podophillyn solution [18], when thirty-five patients with 86 lesions enrolled in this study. The total number of lesions that treated were 76 lesions, 46 (60.53\%) were ulcerated and 30 (39.47\%) lesions were dry, while 10 dry lesions in the covered area were left untreated as a control. Lesions were divided into two groups with matching of type and size of lesions. In group one including 33 (43.42\%) lesions were treated by topical 25\% podophyllin solution once weekly for maximum 6 weeks, while group two consisting 43 (56.58\%) lesions treated with topical 40\% Loranthus europaeus ointment applied daily for maximum 6 weeks. The response to the treatment was assessed by using the modified Sharquie Leishmania score to assess the objective response to the topical or systemic therapy. Follow up was done every 2 weeks for 8 weeks during therapy then monthly for next 3 months. After 6 weeks the cure rate was 84.84\% for lesions treated with podophyllin and $79.07 \%$ for lesions treated with Loranthus europaeus.

When the 2 groups compared with each other there was no statistical significant difference where the $p$ value after 6 weeks was 0.648 .

\section{Conclusion}

As Loranthus europeaus contains many active bioactive agents, further studies are highly recommended for assessing these active medicinal agents for treatment other skin disease as this plant is safe to be used on the skin.

\section{Disclosure}

This study was an independent study and not funded by any drug companies.

\section{References}

[1] WHO (2015) Leishmaniasis: Situation and Trends. World Health Organization. 
http://www.who.int/gho/neglected_diseases/leishmaniasis/en/

[2] Pringle, G. (1975) Oriental Sore in Iraq: Historical and Epidemiological Problems. Bulletin of Endmic Diseases (Baghdad), 2, 41-76.

[3] Sharquie, K.E., Al-Najar, S.A., Noaimi, A.A. and Al-Heany, A.R. (2014) Cutaneous Leishmaniasis: Comparative Techniques for Diagnosis. Journal of Dental and Medical Science, 13, 33-37.

[4] Sharquie, K.E., Najm, R.A., Farjou, I.B. and Al-Timimi, D.J. (2001) Oral Zinc Sulfate in the Treatment of Acute Cutaneous Leishmaniasis. Clinical and Experimental Dermatology, 26, 21-26. http://dx.doi.org/10.1111/j.1365-4632.2008.04010.x

[5] Sundar, S. and Chakravarty, J. (2013) Leishmaniasis: An Update of Current Pharmacotherapy. Expert Opinion on Pharmacotherapy, 14, 53-63. http://dx.doi.org/10.1517/14656566.2013.755515

[6] Thakur, C.P. (1986) Harmful Effect of High Dosage of Sodium Stibogluconate in Treatment of Kala-Azar in India. Ransactions of the Royal Society of Tropical Medicine and Hygiene, 80, 672-673. http://dx.doi.org/10.1016/0035-9203(86)90178-1

[7] Crof, S.L. and Coombs, G.H. (2003) Leishmaniasis-Current Chemotherapy and Recent Advances in the Search for Novel Drugs. Trends in Parasite, 19, 502-508. http://dx.doi.org/10.1016/j.pt.2003.09.008

[8] Alrajhi, A.A., Ibrahim, E.A., De Vol, E.B., Khairat, M., Faris, R.M. and Maguire, J.H. (2002) Fluconazole for the Treatment of Cutaneous Leishmaniasis Caused by Leishmania Major. The New England Journal of Medicine, 346, 891-895. http://dx.doi.org/10.1056/NEJMoa011882

[9] Salmanpour, R., Handjani, F. and Nouhpisheh, M.K. (2001) Comparative Study of the Efficacy of Oral Ketoconazole with Intra-Lesional Meglumine Antimoniate (Glucantime) for the Treatment of Cutaneous Leishmaniasis. Journal of Dermatological Treatment, 12, 159-162. http://dx.doi.org/10.1080/09546630152607899

[10] Nassiri, K.M., Firooz, A., Khamesipour, A., Mojtahed, F., Nilforoushzadeh, M. and Hejazi, H. (2005) A Randomized, Double-Blind, Placebo-Controlled Clinical Trial of Iitraconazole in the Treatment of Cutaneous Leishmaniasis. Journal of the European Academy of Dermatology and Venereology, 19, 80-83. http://dx.doi.org/10.1111/j.1468-3083.2004.01133.x

[11] Ghosn, S.H. and Malek, J.M. (2012) Infestations, Bites and Stings. In: Wolff, K., Goldsmith, L.A., Katz, S.I., Gilchrest, B.A., Paller, A.S. and Leffell, D.J., Eds., Fitzpatrick’s Dermatology in General Medicine, 8th Edition, McGraw-Hill Company, New York, 206, 2527-2537.

[12] Al-Mutaii, N., Alshiltawy, M., El Khalawany, M., Joshi, A., Eassa, B., Manchanda, Y. and Gomaa, S. (2009) Treatment of Old World Cutaneous Leishmaniasis with Dapsone, Itraconazole, Cryotherapy, and Imiquimod, Alone and in Combination. International Journal of Dermatology, 48, 862-869. http://dx.doi.org/10.1111/j.1365-4632.2008.04010.x

[13] Sharquie, K.E. and Al-Talib, K.K. (1988) Intralesional Therapy of Cutaneous Leishmaniasis with Sodium Stibogluconate Antimony. British Journal of Dermatology, 119, 53-57. http://dx.doi.org/10.1111/j.1365-2133.1988.tb07100.x

[14] Sharquie, K.E. (1995) A New Intralesional Therapy of Cutaneous Leishmaniasis with Hypertonic Sodium Chloride Solution. The Journal of Dermatology (Japan), 22, 732-737. http://dx.doi.org/10.1111/j.1346-8138.1995.tb03911.x

[15] Sharquie, K.E., Najem, R.A. and Farjou, I.B. (1997) A Comparative Controlled Trial of Intralesional Administrated Zinc Sulfate, Hypertonic Saline Chloride and Pentavalent Antimony Compound against Acute Cutaneous Leishmaniasis. Clinical and Experimental Dermatology, 22, 169-173. http://dx.doi.org/10.1111/j.1365-2230.1997.tb01054.x

[16] Sharquie, K.E., Al-Waize, M. and Al-Asser, M. (2004) Therapy of Cutaneous Leishmaniasis with Intralesional Metronidazole. Saudi Medical Journal, 10, 1512-1513.

[17] Asilian, A., Jalayer, T., Nilforooshzadh, M., Ghassemi, R.L., Peto, R. and Wayling, S. (2003) Treatment of Cutaneous Leishmaniasis with Aminosidine (Paromomycin) Ointment: Double-Blind Randomized Trial in the Islamic Republic of Iran. Bulletin of the World Health Organization, 81, 353-359.

[18] Sharquie, K.E., Noaimi, A.A. and Al-Ghazzi, A.G. (2015) Treatment of Cutaneous Leishmaniasis by Topical 25\% Podophyllin Solution (Single Blinded, Therapeutic, Controlled Study). Journal of Dermatology \& Dermatologic Surgery, 19, 108-113. http://dx.doi.org/10.1016/j.jdds.2014.10.001

[19] Sharquie, K.E., Al-Mashhadani, S., Noaimi, A.A. and Al-Zoubaidy, W.B. (2015) Microwave Therapy: New Treatment for Cutaneous Leishmaniasis. Our Dermatology Online, 6, 125-129.

[20] Fatima, F., Khalid, A., Nazar, N., Abdalla, M., Mohomed, H., Toum, A.M., Magzoub, M. and Ali, M.S. (2005) In Vitro Assessment of Anti-Cutaneous Leishmaniasis Activity of Some Sudanese Plants. Türkiye Parazitoloji Dergisi, 29, 3-6.

[21] Zerehaz, F., Salmanpour, R., Farhad, H., Aredhali, S., Panjehshahin, M.R., Tabei, S.Z., Tabatabaee, H.R. and Ms, (1990) A Double-Blind Randomized Clinical Trial of a Topical Herbal Extract (Z-HE) vs. Systemic Meglumine Antimoniate for the Treatment of Cutaneous Leishmaniasis in Iran. International Journal of Dermatology, 38, 610-612. 
http://dx.doi.org/10.1046/j.1365-4362.1999.00727.x

[22] Gholami, A., Khamesippour, A., Momeni, A., Ghazanfari, T., Nilforoushzadeh, M.A., Darajeh, Z., et al. (2000) Treatment of Cutaneous Lieshmaniasis with 5\% Garlic Cream: A Randomized, Double-Blind Study. Iranian Journal of Dermatology, 3, 2-6.

[23] Mishra, B.B., Mishra, V.K. and Singh, R.K. (2011) Scope of Natural Product in Fighting against Leishmaniasis. 121154.

[24] Chan-Bacab, M.J. and Pena-Rodriguez, L.M. (2001) Plant Natural Products with Leishmanicidal Activity. Natural Product Reports, 18, 674-688. http://dx.doi.org/10.1039/b100455g

[25] AlShammary, M.N., Magged, R.H. and Mohammed, B.I. (2012) Effect of Phenolic Compound on the Viability of Leishmania tropica Promastigoites: A Comparative in Vitro Study. Al-Qadisyiah Medical Journal, 8, 84-94.

[26] https://en.m.wikipedia.org/wiki/Loranthus

[27] http://www.bgflora.net/families/loranthaceae/loranthus/loranthus europaeus/loranthus europaeus en.html

[28] Guarino, C. and Simone, L.D. (2008) Ethnobotanical Study of the of the Sannio Area, Campania, Southern Italy. Ethnobotany Research \& Applications, 6, 255-317.

[29] Jawad, A.A.H., Al-Rubaee, M.A. and AL-Diab, J.M. (2006) Effects of Loranthus europaeus Seeds on Pyogenic Inflammation in Rabbits. Journal of Missan Researches, 2, 4.

[30] Ahmed, S.A., Al-Shehbaz, I.A. and Al-Mashhadani, A.N. (2013) Vascular Plants of Hawraman Region in Kurdistan Iraq. 165-315.

[31] https://ranslate.google.iq/translate?hl=ar\&sl=it\&tl=en\&u=https\%3A\%2F\%2Fit.m.wikipedia.org\%2Fwiki\%2FLoranth us_europaeus\&sandbox $=1$

[32] Watson, L. and Dallwitz, M.J. (1991) The Families of Angiosperms: Automated Descriptions with Interactive Identification and Information Retrieval. Australian Systematic Botany, 4, 95-681. http://dx.doi.org/10.1071/SB9910681

[33] www.plantsystemtics.org/taxpage/0/genus/loranthus.html

[34] Lakatos, F., Mirtchev, S. and Mehemeti, A. (2014) Hand Book of Major Forest Pests in Southeast Europe. Food and Agriculture Organization of the United Nations, Pristina, 71-100.

[35] Shavvon, R.S., Mehrvarz, S.S. and Golmohammadi, N. (2012) Evidence from Micromorphology and Gross Morphology of the Genus Loranthus (Loranthaceae) in Iran. Turkish Journal of Botany, 36, 655-666.

[36] http://www.wmap.cz/opk/vmp/ros/ros14712.htm

[37] https://commons.m.wikimedia.org/wiki/Loranthus_europaeus

[38] Okuda, T., Yoshida, T., Chen, X.-M., Xie, X.-J and Fukushima, M. (1987) Corianin from Coriaria japonica A. Gray and Sesquiterpene Lactones from Loranthus parasiticus Merr. Used for Treatment of Schizophrenia. Chemical and Pharmaceutical Bulletin, 35, 182-187. http://dx.doi.org/10.1248/cpb.35.182

[39] Sadik, G., Islam, R., Rahman, M.M., Khondkar, P. and Rashid, M.A. (2003) Antimicrobial and Cytotoxic Constituents of Loranthus globosus. Fitoterapia, 74, 308-311. http://dx.doi.org/10.1016/S0367-326X(03)00041-8

[40] Atta-Ur-Rahman, Khan, M.A. and Khan, N.H. (1973) Loranthol: A New Pentacyclic Triterpenoid from Loranthus grewinkii. Phytochemistry, 12, 3004-3006. http://dx.doi.org/10.1016/0031-9422(73)80531-X

[41] Anjaneyulu, A.S.R., Row, L.R. and Reddy, D.S. (1977) Chemical Constituents of Loranthus falcatus Linn. Current Science, 46, 850-851.

[42] Lin, J.H. and Lin, Y.T. (1999) Flavonoids from the Leaves of Loranthus kaoi (Chao) Kiu. Journal of Food and Drug Analysis, 7, 185-190.

[43] Harvala, E., Exner, J. and Becker, H. (1984) Flavonoids of Loranthus europaeus. Journal of Natural Products, 47, 1054-1055. http://dx.doi.org/10.1021/np50036a034

[44] Zhou, H., Zeng, Z., Liu, R. and Chi, Z. (1993) Purification and Characterization of a Cytotoxin from Loranthus Parasiticus Merr. Journal of Sichuan University, 30, 102-106.

[45] Indrani, N., Rao, V.S., Balasubramanian, K., Reddy, K.K. and Vijayaramayya, T. (1980) Studies on Loranthus longiflorus Desr. Tannins. Leather Science, 27, 438-439.

[46] Young, K.K., Young, S.K. and Sang, U.C.H. (2004) Isolation or Flavonol Rhamnoside from Loranthus tanakae and Cytotoxic Effect of Them on Human Tumor Cell Line. Research Articles, Archives of Pharmacal Research, 27, 44-47. http://dx.doi.org/10.1007/BF02980044

[47] Obatomi, D.K., Aina, V.O. and Temple, V.J. (1996) Effects of African Mistletoe Extract on Blood Pressure in Spontaneously Hypertensive Rats. International Journal of Pharmacognosy, 34, 124-127.

http://dx.doi.org/10.1076/phbi.34.2.124.13197 
[48] Obatomi, D.K., Bikomo, E.O. and Temple, V.J. (1994) Anti-Diabetic Properties of the African Mistletoe in Strptozocin-Induced Diabetic Rats. Journal of Ethnopharmacology, 43, 13-17. http://dx.doi.org/10.1016/0378-8741(94)90111-2

[49] Kusumoto, I.T., Shimada, I., Kakiuchi, N., Hattori, M. and Namba, T. (1992) Inhibitory Effects of Indomnesian Plant Extracts on Reverse Transcriptase of an RNA Tumor Virus (I). Phytotherapy Research, 6, 241-244. http://dx.doi.org/10.1002/ptr.2650060504

[50] Hamed, M.N., Numan, I.T. and Hassan, A.F. (2013) Evaluation of Anti-Inflammatory Effect of Ethyl Acetate and Methanol Extract of Loranthus eueopaeus in Experimental Models of Acute Inflammation in Rat. Int. J. Pharm. Sci. Rev. Res, 23, 170-174.

[51] Nuaman, I.T. (2012) Effects of Loranthus europaeus Ethenylacetate and Chloroform Extract on the Growth of Rhabdomyosarcoma and Rat Embryo Fibroblast Cell Line. International Journal of Pharmacy and Pharmaceutical Science, 4, 234-237.

[52] Jawad, A.A.H., AL-Rubaee, M.A. and Al-Diab, J.M. (2007) Oil Extract of Loranthus europaeus Seed Promotes Wounds Healing. Basrah Journal of Veterinary Research, 6.

[53] Al-Fartosy, A.J. and Al-Rikaby, A.K. (2007) Antioxidant Action of Monoterpene from Loranthus europaeus L. Seeds. Al Basra Journal for Agricultural Science, No. 20.

[54] Katsarou, A., Rhizopouiou, S. and Kefalas, P. (2012) Antioxidant Potential of the Aerial Tissues of the Mistletoe Loranthus europeaus Jacq. Record of Natural Product, 6, 349-379.

[55] Gill, L.S. and Hawksworth, F.G. (1961) The Mistletoes: A Literature Review. Technical Bulletin, 1242, 2-24.

[56] Wright, C.W. and Phillipson, J.D. (1990) Natural Product and Development of Selective Antiprotozoal Drugs. Phytotherapy Research, 4, 127-139. http://dx.doi.org/10.1002/ptr.2650040402

[57] Huynh, C., Sacks, D.L. and Andrews, N.W. (2006) A Leishmania amazonenissis Family Iron Transporter Is Essential for Parasite Replication within Macrophage Phagolysosome. The Journal of Experimental Medicine, 203, 2363-2375. http://dx.doi.org/10.1084/jem.20060559

[58] Leopoldi, M., Russo, N. and Chiodo, S. (2006) Iron Chelation by the Powerful Antioxidant Falavonoid Quercetin. Journal of Agricultural and Food Chemistry, 54, 6343-6351. http://dx.doi.org/10.1021/jf060986h

[59] Sen, G., Mukhopadhyay, S., Ray, M. and Biswas, T. (2008) Quercetin Interferes with Iron Metabolism in Leishmania donovani and Target Ribonucleotide Reductase to Exert Leishmanicidal Activity; in Vivo Study. Journal of Antimicrobial Chemotherapy, 61, 1066-1075.

[60] Minura, Y.H., Tomita, I., Watanabe, T. and Hirayama, T. (1998) Active Oxygen Generation by Flavonoids. Biological and Pharmaceutical Bulletin, 21, 93-96. http://dx.doi.org/10.1248/bpb.21.93

[61] Slilva, F.F., Inacio, J.D.F. and Cavalheiro, M.M.C. (2011) Reactive Oxygen Species Production and Mitochondrial Dysfunction Contribute to Quercetin Induced Death in Leishmania amazonesis. PLoS ONE, 6, e14666.

[62] Romo, T. (2004) Wound Healing. Skin J. E. Medicine, 111.

[63] Lorena, D. (2002) Normal Scaring: Importance of Myofibroblast. Wound Repair \& Regeneration, 10, 86-92. http://dx.doi.org/10.1046/j.1524-475X.2002.00201.x

[64] Shah, M., Foreman, D.M. and Ferguson, M.W.J. (1992) Control of Scaring in Adult Wound by Neutralizing Antibodies to Transforming Growth Factors Beta. The Lancet, 339, 213-214. http://dx.doi.org/10.1016/0140-6736(92)90009-R

[65] Irvin, T.T. (1985) Wounds and Wound Healing. Archives of Emergency Medicine, 2, 3.

[66] Davis, R.H. and Maro, N.P. (1989) Aloe vera and Gibberellin. Anti-Inflammatory Activity in Diabetes. Journal of the American Podiatric Medical Association, 79, 24-26.

[67] Rubin, M.B. (1984) Vitamins \& Wound Healing. Plastic Surgical Nursing, 4, 16-19. http://dx.doi.org/10.1097/00006527-198400410-00003

[68] Bigbie, R.B. Schumacher, J., Swaim, S.F. and Purohit, R.C. (1991) Effect of Ammonia and Life Yeast Cell Derivative on Second Intention Healing in Horses. Am. J. Vet. Res., 52, 176-1382.

[69] Surguna, L., Sivakummar, P. and Chandrakasan, G. (1996) Effects of Centella asisatica Extract on Dermal Wound Healing in Rats. Indian Journal of Experimental Biology, 34, 1208-1211.

[70] Ubaid, J.A., Ahmed, S.H. and Al-Saaedy, K.M. (2012) The Activity of Hot Watery and Alcoholic Extract of Seeds of Loranthus euroupaeus in Treatment of Burns. International Journal for Science and Technology, 7, 115-121.

[71] Tzianabos, A.O. (2000) Polysaccharide’s Immunomodulator as Therapeutic Agent. Clinical Microbiology Review, 13, 523-533.

[72] Henson, P.M. and Johonsto, R.B. (1987) Tissue Injury in Inflammation, Oxidant Proteinases and Cationic Proteins. 
The Journal of Clinical Investigation, 79, 669-674. http://dx.doi.org/10.1172/JCI112869

[73] Möse, J. (1983) Effect of Echinacin on Phagocytosis and Natural Killer Cells. Die Medizinische Welt, 34, $463-467$.

[74] Melzer, J, Iten, F., Hostanska, K. and Saller, R. (2009) Efficacy and Safety of Mistletoe Preparation (Viscum album) for Patients with Cancer Disease. Forschende Komplementärmedizin, 16, 217-226. http://dx.doi.org/10.1159/000226249

[75] Stumpf, C., Rosenberger, A. and Rieger, S. (2000) Mistletoe Extract in the Therapy of Malignant Hematological and Lymphatic Disease: A Monocentric, Respective Analysis over 16 Years. Forschende Komplementärmedizin, 7, 139146. http://dx.doi.org/10.1159/000021330

[76] Lee, T. and Chen, C.L. (2009) Study on Antioxidant Activity of Echinaceea purpura L. Extract and Its Impact on Cell Viability. African Journal of Biotechnology, 8, 5097-5105.

[77] Cholkova, M., Christov, D.V., Dimitrova, L. and Evtativa, R. (2002) Flavonoids and Terpenoides Isolated from Loranthus europaeus with Stimulatory Effect on Lymphocyte Proliferation. Experimental Pathology and Parasitology, 91, 45-48.

[78] Arman, Z., Zarshenas, M.M. and Aliasghar, K. (2013) Management of Stroke as Described by Ibn Sina (Avicenna) in Canon Medicine. International Journal of Cardiology, 5, 233-237.

[79] Hassan, A.F., Numan, I.T., Al-Sammarrae, K.W. and Hussain, S.A. (2011) Hematopoietic Toxicity of Loranthus europeus Chloroform Extract: In-Vitro Study. Pharmacie Globale International Journal of Comprehensive Pharmacy, 2 , $1-4$.

[80] Al-Azawi, A.F., Numan, I.T. and Al-Sammarrae, K.W. (2011) Genotoxic Study of Different Extract of Loranthus europeaus Fruits on Bone Marrow and Spleen Cells of Mice: In-Vivo Study.

[81] Sharquie, K.E., Noaimi, A.A. and Saleh, B.A.M. (2015) Topical 40\% Loranthus europaeus Ointment Versus Topical 25\% Podophyllin Solution in the Treatment of Acute Cutaneous Leishmaniasis (Single Blinded, Therapeutic, Comparative study). A Thesis Submitted to the Scientific of Dermatology \& Venereology as a Partial Fulfillment for the Degree of Fellowship of Iraqi Board for Medical Specializations in Dermatology \& Venereology. 